\title{
EMOTIONAL INTELLIGENCE, SPIRITUAL INTELLIGENCE AND EMPLOYEE PERFORMANCE: THE MEDIATING ROLE OF COMMUNICATION COMPETENCE
}

\author{
Anita Rahmawaty* \\ Institut Agama Islam Negeri Kudus, Indonesia \\ Wahibur Rokhman \\ Institut Agama Islam Negeri Kudus, Indonesia \\ Anton Bawono \\ Institut Agama Islam Negeri Salatiga, Indonesia \\ Nafis Irkhami \\ Institut Agama Islam Negeri Salatiga, Indonesia
}

\begin{abstract}
The purpose of this study is to analyze the influence of emotional intelligence and spiritual intelligence on employee performance and the role of communication competence in mediating the influence of emotional intelligence and spiritual intelligence on employee performance. The samples are selected from employees $(n$ = 196) of Islamic Microfinance Institutions in Pati, Central Java, Indonesia. The results of path analysis reveal that emotional intelligence and spiritual intelligence have a positive and significant influence on communication competence and employee performance, and communication competence partially mediates the influence of emotional intelligence and spiritual intelligence on employee performance. Therefore, it is recommended that Islamic Microfinance practitioners should improve employee performance through emotional intelligence, spiritual intelligence, and communication competence.
\end{abstract}

Keywords: Emotional Intelligence, Spiritual Intelligence, Communication Competence, Employee Performance.

Received: 13 June 2020

Accepted: 10 May 2021

https://doi.org/10.33736/ijbs.3754.2021

\section{INTRODUCTION}

The international definition of microfinance institutions is institutions of the formal, semiformal and informal financial sectors providing small-scale financial services to the lower segments of the population (Seibel \& Dwi Agung, 2005), while according to the Indonesia Financial Services Authority (Otoritas Jasa Keuangan (OJK), 2020), microfinance institutions are financial institution established specifically to provide business development services and community empowerment through loans and financing of micro business to its members and community, management of

\footnotetext{
- Corresponding author: Faculty of Islamic Economics and Business, Institut Agama Islam Negeri Kudus, Indonesia, Jl. Conge Ngembalrejo PO. BOX. 51 Kudus; E-mail: itarahma1275@gmail.com.
} 
deposits, and business development consultation which are not solely for profit, both under conventional and sharia principles (OJK, 2020). In 2012, only $0.005 \%$ of global MFIs are Islamic microfinance institutions and these institutions are concentrated in Indonesia, Bangladesh and Pakistan (Fianto \& Gan, 2017).

Islamic microfinance institutions play an important role in initiating the establishment of an Islamic financial institution in Indonesia. The microfinance institutions in Indonesia are the most differentiated in the world with three categories: formal, semi-formal, and informal. Considering a large number of Muslim populations, Islamic microfinance institutions have a high opportunity to grow in Indonesia, however, some challenges hamper its growth (Fianto \& Gan, 2017), and therefore, this study aims to examine the factors that affect Islamic microfinance performance in Indonesia from the human resource point of view.

Human resources are an important asset for the advancement and development of an organization. The success of an organization is not only influenced by achieving productivity but also employee performance in the process of achieving that productivity. In other words, performance is the primary key for every individual and organization in reaching productivity (Rapareni, 2013). Therefore, every organization strives to improve its employee performance in reaching the organizational goals. Despite this, employee performance always leaves behind a problem that has to be addressed by management; therefore, management needs to understand the factors that influence employee performance.

One of the measurements of employee performance is an intellectual ability, which is supported by the capability to master knowledge, manage oneself, as well as fosters relationships with other people. Fitriastuti (2013) states that finding the right people in an organization is not an easy task. This is because people who are needed in an organization are not only those with higher education or those have high talent, these people are also selected based on their psychological factors that influence their ability in an organization, such as the capability to manage oneself, have initiatives, be optimistic, manage one's emotions, and think calmly without involving one's emotions.

Goleman (1995) defines this ability as emotional intelligence which contributes to $80 \%$ of the determinant factors of life success. Abilities such as being able to motivate oneself and persist in the face of frustrations; to control impulse and delay gratification; to regulate one's mode and keep the distress from swamping the ability to think; to empathize and to hope. As for the other $20 \%$ is determined by one's IQ (intelligence quotient). Previous studies have also found that emotional intelligence has a positive and significant influence on employee's performance (Trihandini, 2005; Fitriastuti, 2013) and supervisor's performance (Eman, 2014).

Another type of intelligence that currently receives society's interest is spiritual intelligence. Spiritual intelligence is the ability to integrate two other capabilities, the IQ and EQ, so that it enables someone to think creatively, have a future insight, and make the individual work better. Zohar and Marshal (2000) discover that spiritual intelligence can make a human become a complete being intellectually, emotionally, and spiritually. Similar to the statement above, Rahmasari (2012) finds that an individual's intelligence is not only proven by possessing a high IQ, but that person should also have spiritual intelligence.

Besides emotional intelligence and spiritual intelligence, communication is another important 
aspect of one's work life. Good communication can increase mutual understanding, cooperation, and job satisfaction. Conversely, poor communication has a wider effect on the organization, such as conflicts between employees. Keeping in mind that individuals who work together in an organization are a group of human resources that have various characteristics and personalities. Employees who have good communication competence will be able to complete their assigned tasks so that the employee performance will be better (Rapareni, 2013).

Several empirical studies have revealed the connection between communication competence and trust, organizational commitment, job satisfaction, and employee performance. A study by Castro (2013) finds that organizational satisfaction mediates the relationship between communication competence on trust and job satisfaction. Research from Zeffane et al. (2011) examines the role of trust in moderating the relationship between communication effectiveness and organizational commitment. A study from Rapareni (2013) shows that communication competence has a positive and significant effect on employee performance at RRI. Meanwhile, a study conducted by Eman (2014) reveals that communication effectiveness is not mediated by the influence of emotional intelligence on supervisor performance at PT Dock and Shipping Surabaya. The findings from the previous studies show that there is gap concerning the relationship between communication competence, emotional intelligence, job satisfaction, and employee performance, which motivate this study to test the mediating role of communication competence on the relationship between employee's intelligence and performance.

Based on a review of the previous research mentioned above, it reveals that emotional intelligence and spiritual intelligence have a positive and significant influence on employee performance in various government and private institutions, for industry and commerce organizations, supervisors of PT Dock and Shipping, RRI, and the hotel industry. Therefore, this research specifically tests the influence of emotional intelligence and spiritual intelligence on employee performance at Islamic Microfinance Institutions, which has rapid development in Indonesia recently.

There have been several research findings on the determinant factors of employee performance. However, to the best of researcher's knowledge, there has not been any known research that specifically tests communication competence in mediating the influence between emotional intelligence and spiritual intelligence on employee performance in Islamic Microfinance context. Thus, this research will examine the role of communication competence in mediating the effect of emotional intelligence and spiritual intelligence on employee performance at Islamic Microfinance Institutions in Pati residence.

The objectives of this research are to analyze the influence of emotional intelligence and spiritual intelligence on employee performance and the role of communication competence in mediating the influence of emotional intelligence and spiritual intelligence on employee performance. This research is expected to contribute to developing knowledge in the Islamic economy, especially in improving employee performance at Islamic Microfinance Institutions through emotional intelligence, spiritual intelligence, and communication competence. The Islamic Microfinance Institutions practitioners can also understand the determinant factors of employee performance so that they can determine company policies to develop the business. 


\section{LITERATURE REVIEW}

\subsection{Emotional Intelligence, Communication Competence, and Employee Performance}

The term "emotional intelligence" was first devised in 1990 by psychologists, Peter Salovey from Harvard University and John Mayer from the University of New Hampshire, the United States. Salovey and Mayer (1990) and Labbaf et al. (2011), state that "Emotional intelligence is the ability to monitor one's own and others' emotions, to discriminate among them, and use the information to guide one's thinking and actions." This viewpoint shows that emotional intelligence is the capability to understand one's own emotions and others' emotions and to be able to differentiate and use the information to guide one's thinking and actions.

Despite that, emotional intelligence became popular and started to spread in 1995 due to the best seller book written by Goleman called "Emotional Intelligence", which was published and became the headline of a Time magazine edition (Labbaf et al., 2011). Many definitions of emotional intelligence have been created by experts. Goleman (1995), as quoted by Labbaf et al. (2011) defined it as: “...emotional intelligence....refers to the capacity for recognizing our own feelings and those of others, for motivating ourselves, and for managing emotions well in ourselves and in our relationships....".

In other words, emotional intelligence is defined as the capacity to comprehend one's feelings and those of others, the capacity to motivate oneself, to manage one's emotions well, and in managing their relationships with other people. Emotional intelligence is considered to encompass different capabilities, but they complete the academic intelligence, which is a pure cognitive ability measured with IQ.

Dulewicz and Higgs (2000) and John (2011) state: Emotional intelligence is about knowing what you are feeling, and being able to motivate yourself to get jobs done. It is sensing what others are feeling and handling relationships effectively."

The opinion above states that emotional intelligence is about how someone knows what is being felt and can motivate oneself to do one's tasks better so that the individual can maintain better relations with others.

Meanwhile, Hein (2007) and Yadav (2011) clarify that: "Emotional intelligence is the innate potential to feel, use, communicate, recognize, remember, describe, identify, learn from, manage, understand, and explain emotions." In other words, emotional intelligence is the potential from within oneself to be able to feel, utilize, communicate, comprehend, recall, and identify emotions.

Based on the various definitions above, it can be understood that emotional intelligence is the capability of someone to be able to know oneself and others better so that it will create harmonious relationships with others.

Goleman (1995) and Labbaf et al. (2011) reveal the five dimensions of emotional intelligence as follows: (1) self-awareness: an individual's ability to understand various inner potentials related to the strength or weaknesses of an individual; (2) self-regulation: a person's capability to control or regulate one's inner emotions; (3) self-motivation: self-motivation; (4) social awareness: an understanding and sensitivity towards the other's feelings, mindset, and situations; and (5) social 
skills: the ability to engage in social relationships.

A study by Trihandini (2005) reveals that emotional intelligence has a positive and significant influence on employee performance at Hotel Horison Semarang. This finding is also supported by a study from Fitriastuti (2013), which demonstrates that emotional intelligence has a positive and significant influence on the civil servant performance in the Department of Industry and Commerce of East Kutai Regency. A study by Eman (2014) on supervisors at PT Dock and Shipping Company in Surabaya concludes that emotional intelligence has a positive and significant influence on the supervisor's performance. Meanwhile, a research conducted by Rapareni (2013) supports the hypothesis that emotional intelligence has a positive and significant influence on employee performance at Radio Republik Indonesia (RRI), which is also supported by the findings from Rahmasari (2012), in which emotional intelligence has a positive and significant influence on employee performance. In other words, emotional intelligence is one of the important aspects that affect communication competence and employee performance. The following hypotheses were proposed:

\section{$H_{1}$ : Emotional intelligence has a positive and significant influence on communication competence.}

\section{$H_{3}$ : Emotional intelligence has a positive and significant influence on employee performance.}

\subsection{Spiritual Intelligence, Communication Competence, and Employee Performance}

Spiritual intelligence combines the constructs of spirituality and intelligence into a new construct. Many definitions of spiritual intelligence have been provided by various experts. Emmons (1999) and Amram (2009) provided the following definition: "Spiritual intelligence is a framework for identifying and organizing skills and abilities needed for the adaptive use of spirituality". Zohar and Marshall (2000) explained that spiritual intelligence is: "The intelligence with which we address and solve problems of meaning and value, the intelligence with which we can place our actions and our lives in a wider, richer, meaning-giving context, the intelligence with which we can assess that one course of action or one life-path is more meaningful than another."

The definition above shows that spiritual intelligence is the intelligence to face and solve problems surrounding meanings and values, the intelligence to place behavior and life in a wider context of meaning, as well as the intelligence to evaluate the behavior or life path of an individual to gain more value and meaning compared to another person (Liling et al., 2013). Spiritual intelligence is a soul intelligence or wisdom intelligence. This intelligence is an inherited capacity of the human brain. It is a spirituality based on structures within the brain that provide us with the basic ability to shape meanings, values, and goals. Therefore, an individual need to find, manage and optimize or utilize one's wisdom values to reach an honorable goal or a purpose that makes oneself have meaning (a meaningful life) (Sina \& Noya, 2012).

Wolman (2001) and Amram (2009) states that spiritual intelligence is "The human capacity to ask ultimate questions about the meaning of life and to simultaneously experience the seamless connection between each of us and the world in which we live." Amram (2009) considers that 
spiritual intelligence is: "The ability to apply, manifest, and embody spiritual resources, values, and qualities to enhance daily functioning and wellbeing".

Zohar and Marshall (2000) reveal that spiritual intelligence can make human complete a creature in terms of intellect, emotions, and spirituality. A similar sentiment was also mentioned by Rahmasari (2012) that being smart does not necessitate having a high IQ, but to be smart, a person should have spiritual intelligence. In other words, spiritual intelligence is being able to integrate two other abilities, IQ and EQ. Spiritual intelligence allows a person to think creatively, have future insight, and make or even change regulations to let the person work more effectively.

Spiritual intelligence is established due to a debate between IQ and EQ. Therefore, this term arose because IQ and EQ are considered as the only contributing part of a person's determinants for success in life, in which other factors also play a role, which means that spiritual intelligence emphasizes more on the meaning of life and is not limited to a religious aspect (Trihandini, 2005). Spiritual intelligence is an intelligence that plays a role as a framework that is needed in having an effectively functioning IQ and EQ. This statement implies that SQ alone cannot solve a problem, because a balance is needed between one's emotional intelligence and intellect. Thus, IQ, EQ, and SQ should have proportional synergy, produce the strengths of one's body and soul in a complete balance (Rahmasari, 2012).

Meanwhile, Sina and Noya (2012) state that spiritual intelligence is a combination of many factors, including inner capacity (mysticism), transcendent ability, and the skill to strive to a high level from spiritual awareness, understand spiritual meanings in daily activities, use spiritual resources to solve problems, and become moral and noble. Thus, spiritual intelligence involves a life vision and not just goals of life. Spiritual intelligence is about life totality, even the whole universe so that self-awareness and inner reflections are needed to understand spiritual intelligence.

Sabiq and Djalali (2012) also state that spiritual intelligence is more of a concept that related to how a person is smart in managing and making use of meanings, values, and spiritual life qualities, which cover: the will to find for a meaning in life, which motivates humans to always look for the meaning of life and strive for a meaningful life. Spiritual intelligence can be directed towards a spiritual wisdom pinnacle with being honest, tolerant, full of love, and caring towards others.

Zohar and Marshall (2000) discover that spiritual intelligence consists of the following dimensions: (1) the ability to be flexible; (2) a high level of awareness; (3) the ability to face and take advantage of challenging things; (4) the ability to face and heal a sickness which is marked by the appearance of a forgiving and sincere attitude; (5) a life quality which is inspired by a vision and values of righteousness; (6) a tendency to think before acting; (7) a holistic viewpoint, which is the ability to think logically and behave according to social norms; (8) the ability to imagine and have a high desire for knowledge; and (9) the ability to work independently.

As mentioned earlier, spiritual intelligence played an important role in influencing employees' performance. Spiritual intelligence is an important aspect in achieving employee productivity and effectiveness. Spiritual intelligence is found to have a positive and significant influence on employee performance at Hotel Horison Semarang (Trihandini, 2005). This result is also supported by a study conducted by Rahmasari (2012), who proves that spiritual intelligence has a positive and significant influence on employee performance. Various previous researches also support the 
notion that spiritual intelligence plays a significant role in shaping an individual's attitude and behavior, such as procrastination and pro-social behavior, as found in a research conducted by Liling et al. (2013) and Sabiq and Djalali (2012). The evidence suggests that spiritual intelligence is positively and significantly related to employee performance. Thus, it was hypothesized as follow:

\section{$\mathrm{H}_{2}$ : Spiritual intelligence has a positive and significant influence on communication competence. \\ $H_{4:}$ Spiritual intelligence has a positive and significant influence on employee performance.}

\subsection{Communication Competence and Employee Performance}

Communication is an important part of the working world because it has wide effects on organizational life. The experts have devised numerous definitions of 'communication'. Zeffane et al. (2011) define communication as formal as well as informal sharing of meaningful and timely information. Eman (2014) explain that communication as a process to share meaning through verbal and non-verbal processes. Communication is conveying or exchanging information from the sender to the recipient, whether through a verbal or written manner or by using a communication device. Thus, in general, it can be concluded that communication is a process of forming, conveying, accepting, and processing a message that occurs from within an individual and/or between two or more individuals with a particular purpose.

Communication has an important role in an organization because it has a positive effect on employees' work enthusiasm, which in the end can support employees in achieving work productivity. Communication can reinforce employees' motivation by explaining what needs to be done, how well they do a task, and what needs to be done to improve their performance if it is below the standards (Eman, 2014). To implement the functions of that communication, communication competence is needed. Employees who have good communication competence will be able to obtain and carry out the tasks assigned to them well.

Nowadays, the communication competence concept refers to the original criteria of Spitzberg and Cupach, which are the appropriateness and effectiveness. Rapareni (2013) defines communication competence as some resources owned by a communicator that is used in the communication process. Spitzberg and Cupach (in Rapareni, 2013) define communication competence as an evaluative impression of the quality of interactions that are bridged by organizational norms and regulations. In other words, communication competence is evaluating the success of communication where the goals of interacting are fulfilled through the appropriate and effective messages within the organizational context. Likewise, Novianty (2015) find that communication competence is the ability to effectively convey messages or evaluations of related communication to achieve the goals of a specific situation.

Spitzberg and Cupach (in Rapareni, 2013) described the dimensions of communication competence as follows: (1) communication motivation, which is the willingness of an individual to approach or avoid interactions with others, such as a scared or embarrassed feeling to communicate, to arrange interactions, and adjust communication within an organization; (2) 
communication knowledge, which is in the form of procedural knowledge to arrange and implement a scenario in different social situations and have the ability to "read" social situations; and (3) communication skills, which cover actual performance from behavior. Communication skill is often a difficult part for communicators because they have to change their motivations and plans to become actions. An individual is often motivated to communicate and have the knowledge, but the person may lack actual communication skills. The skills needed by an organization are fostering relationships, observing and following instructions, providing feedback, exchanging information, looking for feedback, and solving problems.

Communication competence is needed by an employee when they complain about job-related matters to their supervisor. The employee must know the proper way to communicate to his/her supervisor (motivation to communicate) and be able to read situations to understand the appropriate time to make a complaint (knowledge to communicate). Communication competence (the skill to communicate) is also needed to be able to explain the message conveyed so that the communication process is effective and creates the same perception. A skill to communicate is also necessary for a situation that requires an individual to be able to communicate in solving a problem (Novianty, 2015). Thus, an individual who has communication competence will be able to know how to minimize problems in communicating with other people, control one's emotions, show respect, be polite, and use polite language in communicating.

In Indonesia, Rapareni (2013) shows that communication competence has a positive and significant effect on employee performance at RRI. Performance refers to the outcome of quality or quantity that is achieved by an individual in conducting tasks based on the standards or criteria that have been established (Taurisa \& Ratnawati, 2012). This evidence suggests that communication competence is positively and significantly related to employee performance. Thus, it is hypothesized as follow:

\section{$H_{5:}$ Communication competence has a positive and significant influence on employee performance.}

\subsection{Mediation Effect of Communication Competence}

In general, a given variable functions as a mediator to the extent that it explains the relationship between the predictor and the criterion (Baron \& Kenny, 1986). This study predicts that communication competence will mediate the effect of emotional intelligence on employee performance and spiritual intelligence on employee performance.

As mentioned earlier, the emotional intelligence has a significant positive effect on employee performance as explained by Trihandini (2005), Fitriastuti (2013), Eman (2014), Rapareni (2013), and Rahmasari (2012). The relationship between communication competence and employee performance has been explained by Rapareni (2013). This evidence suggests that communication competence mediate the relationship between emotional intelligence and spiritual intelligence on employee performance. Thus, it was hypothesized as follow:

\section{$H_{6:}$ Communication competence mediates the influence of emotional intelligence on employee performance.}




\section{$H_{7:}$ Communication competence mediates the influence of spiritual intelligence on employee performance.}

Figure 1 illustrates the research model that summarizes the constructs and hypothesis developed in this study.

Figure 1. Research Model

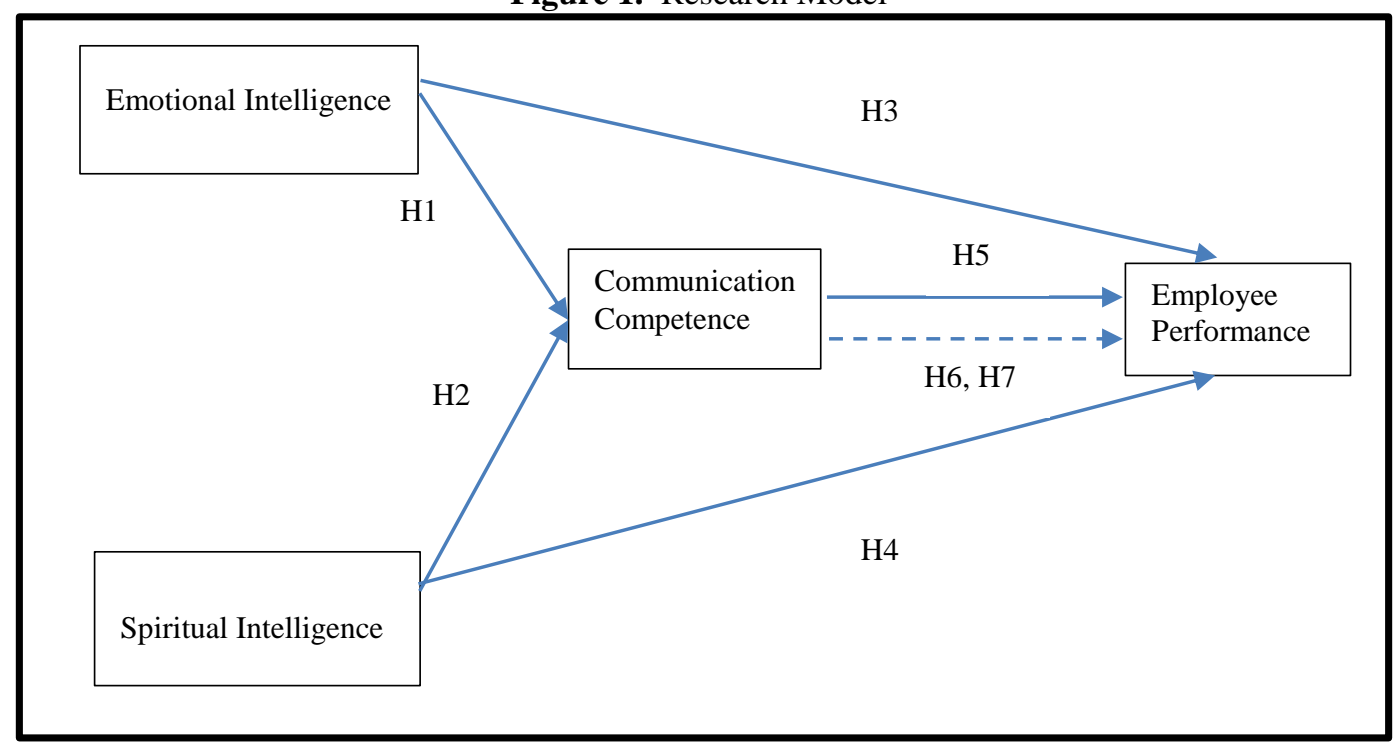

\section{METHODOLOGY}

\subsection{Population and Sample}

The population of this research is all employees of Islamic Microfinance Institutions in Pati region, Central Java, Indonesia. Considering the relatively large population and limited time to conduct the research, a research sample was taken from the population. There are 196 Islamic Microfinance Institutions employees in Pati region, Central Java, Indonesia that is selected as the research sample. The total number of samples selected refers to Hair et al. (2006). The data are analyzed using path analysis in AMOS 16.0 statistics software.

\subsection{Variable Measurements}

There are four variables in this research: emotional intelligence, spiritual intelligence, communication competence, and employee performance. This research used a questionnaire as the research instrument. The items for each variable are adopted from previous studies. The example for the items used in the questionnaire is presented in Table 1. In total, there are 47 items included in the research instrument and all of the items are measured using a 5-point Likert scale (starting from ' 1 ' = strongly disagree to ' 5 ' = strongly agree). 
Table 1: Questionnaire Items and References

\begin{tabular}{clcl}
\hline \hline No & \multicolumn{1}{c}{ Research Variables } & Items & \multicolumn{1}{c}{ References } \\
\hline 1 & Emotional Intelligence & 15 & Labbaf et al. (2011) \\
2 & Spiritual Intelligence & 9 & Zohar \& Marshall (2000) \\
3 & Communication Competence & 12 & Payne (2005) \\
4 & Employee Performance & 11 & Tsui et al. (1997) \\
\hline \hline
\end{tabular}

\subsection{Validity and Reliability}

This research selects variables which reliability and validities have been verified from previous studies. A reliability test was used to assess the consistency of the result measurements; and a validity test was used to test the goodness of the measure. The coefficient alpha is the most popular measure of reliability for a multi item scale. Values were all above 0.70 . Each construct yielded the following reliabilities: Cronbanch alpha coefficient for emotional intelligence was 0.894, spiritual intelligence 0.858 , communication competence 0.916 and employee performance 0.923 .

Table 2: Reliability Test

\begin{tabular}{lcc}
\hline \hline \multicolumn{1}{c}{ Variable } & Cronbach Alpha & Result \\
\hline Emotional Intelligence & 0.894 & Reliable \\
Spiritual Intelligence & 0.858 & Reliable \\
Communication Competence & 0.916 & Reliable \\
Employee Performance & 0.923 & Reliable \\
\hline \hline
\end{tabular}

\section{RESULTS AND DISCUSSION}

\subsection{Respondents' Characteristics}

There is a total of 196 respondents who provide their responses to the questionnaire. Respondent's characteristics including gender, age, education level, length of employment, and employee position, are provided in Table 3. 
Table 3: Respondent's Characteristics

\begin{tabular}{|c|c|c|}
\hline Characteristics & Total & Percentage \\
\hline \multicolumn{3}{|l|}{ Gender } \\
\hline - Male & 127 & 65 \\
\hline - Female & 69 & 35 \\
\hline Total & 196 & 100 \\
\hline \multicolumn{3}{|l|}{ Age } \\
\hline - $20-24$ years old & 42 & 22 \\
\hline - $\quad 25$ - 29 years old & 73 & 37 \\
\hline - $\quad 30-34$ years old & 49 & 25 \\
\hline - $\quad 35$ - 39 years old & 20 & 10 \\
\hline - $\quad>40$ years old & 12 & 6 \\
\hline Total & 196 & 100 \\
\hline \multicolumn{3}{|l|}{ Education level } \\
\hline - High school & 126 & 64 \\
\hline - Associate Degree (Diploma) & 28 & 14 \\
\hline - $\quad$ Undergraduate Degree (S1) & 42 & 22 \\
\hline Total & 196 & 100 \\
\hline \multicolumn{3}{|l|}{ Length of employment } \\
\hline - $\quad 1-2$ years & 20 & 10 \\
\hline - $3-4$ years & 42 & 20 \\
\hline - $5-6$ years & 78 & 40 \\
\hline - $\quad>7$ years & 56 & 28 \\
\hline Total & 196 & 100 \\
\hline \multicolumn{3}{|l|}{ Employee position } \\
\hline - Marketing & 89 & 46 \\
\hline - Teller & 28 & 14 \\
\hline - $\quad$ Finance administration & 35 & 18 \\
\hline - Account officer (AO) & 20 & 10 \\
\hline - Internal auditor & 12 & 6 \\
\hline - $\quad$ Risk finance & 12 & 6 \\
\hline Total & 196 & 100 \\
\hline
\end{tabular}

\subsection{Model Estimation Test and Hypothesis Testing}

After performing a path analysis model assumption test, which included data normality test, outlier test, multicollinearity test, and singularity test, the results revealed that all of the conditions could be met, so that the testing is continued using the following path analysis model: 
Figure 2: Path Analysis Model

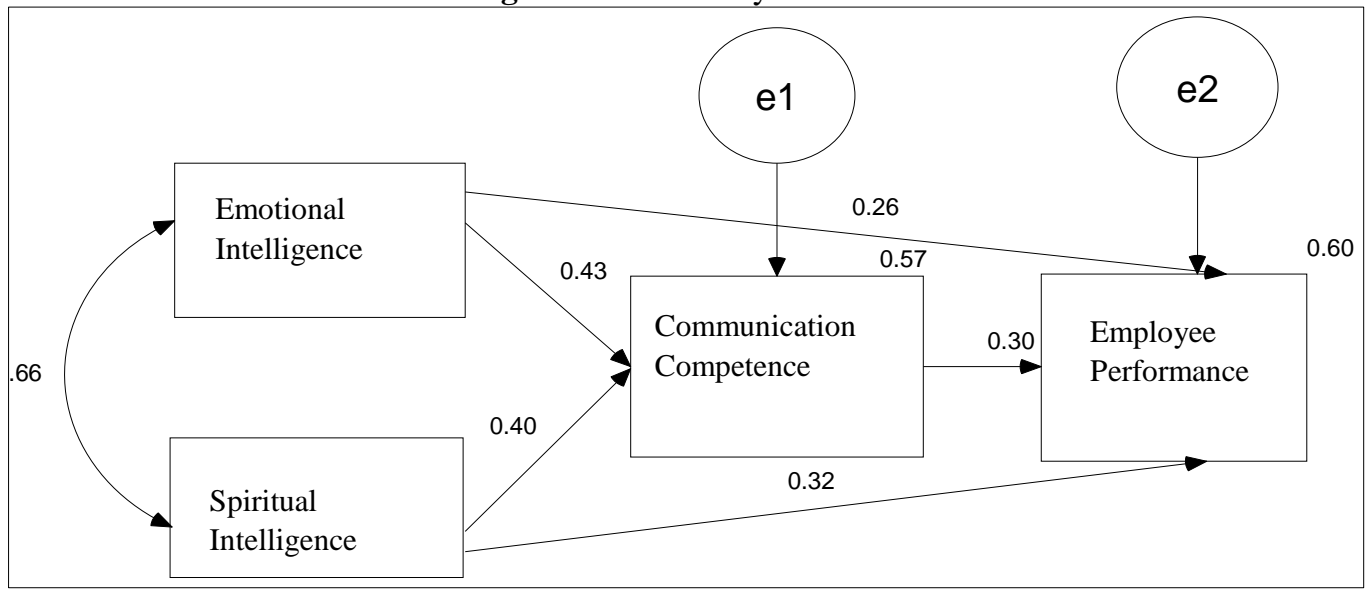

The path analysis test results can be seen in Table 4 .

Table 4: Path Analysis Test Results

\begin{tabular}{cccccc}
\hline \hline $\begin{array}{c}\text { Independent } \\
\text { Variable }\end{array}$ & $\begin{array}{c}\text { Dependent } \\
\text { Variable }\end{array}$ & $\begin{array}{c}\text { Standardized } \\
\text { Path } \\
\text { Coefficients }\end{array}$ & C R & Prob. & $\begin{array}{c}\text { Squared } \\
\text { Multiple } \\
\text { Correlations } \\
\left(\mathbf{R}^{2}\right)\end{array}$ \\
\hline $\begin{array}{c}\text { Emotional } \\
\text { Intelligence } \\
\text { Spiritual } \\
\text { Intelligence } \\
\text { Emotional } \\
\text { Intelligence } \\
\text { Spiritual } \\
\text { Intelligence }\end{array}$ & $\begin{array}{c}\text { Communication } \\
\text { Competence }\end{array}$ & 0.428 & 6.843 & $0.000 * *$ & 0.571 \\
Communication & Employee & 0.400 & 6.394 & $0.000 * *$ & \\
Competence & Performance & 0.315 & 4.765 & $0.000 * *$ & 0.604 \\
\hline \hline
\end{tabular}

Notes: ** significant at $5 \%$ level

Based on the output results of the standardized path coefficients above, the testing results of the research hypotheses are:

a. The Influence of Emotional Intelligence on Communication Competence

Based on the calculated results, it was found that the standardized path coefficient is 0.428 with a significance value in the critical ratio (CR) of 6.843 and a significance standard of 0.000 . Since the significance value is $<0.05$, the alternative hypothesis is supported and it can be concluded that emotional intelligence has a positive and significant influence on communication competence. Thus, the first hypothesis is statistically proven. 
b. The Influence of Spiritual Intelligence on Communication Competence

Based on the results of the analysis, it was found that the standardized path coefficient is 0.400 with a significance value of the critical ratio (CR) of 6.394 and a significance standard of 0.000 . Since the significance value is $<0.05$, the alternative hypothesis is supported and it can be concluded that spiritual intelligence has a positive and significant influence on communication competence. Thus, the second hypothesis is statistically proven.

c. The Influence of Emotional Intelligence on Employee Performance

Based on the calculated results, it was established that the standardized path coefficient is 0.257 with a significance value of the critical ratio (CR) of 3.829 and a significance standard of 0.000 . Since the significance value is $<0.05$, the alternative hypothesis is supported and it can be concluded that emotional intelligence has a positive and significant influence on employee performance. Thus, the third hypothesis is statistically proven.

\section{d. The Influence of Spiritual Intelligence on Employee Performance}

Based on the tabulated results, it was discovered that the standardized path coefficient is 0.315 with a significance value of the critical ratio (CR) of 4.765 and a significance standard of 0.000 . Since the significance value is $<0.05$, the alternative hypothesis is supported and it can be concluded that spiritual intelligence has a positive and significant influence on employee performance. Thus, the fourth hypothesis is statistically proven.

\section{e. The Influence of Communication Competence on Employee Performance}

Based on the calculated results, it was revealed that the standardized path coefficient is 0.304 with a significance value of the critical ratio (CR) of 4.421 and a significance standard of 0.000 . Since the significance value is $<0.05$, the alternative hypothesis is supported and it can be concluded that communication competence has a positive and significant influence on employee performance. Thus, the fifth hypothesis is statistically proven.

f. Communication Competence mediates the influence of Emotional Intelligence on Employee Performance

The results of the path test (path analysis) showed that the independent variable (emotional intelligence) has a direct significant effect on the mediating variables (communication competence) and then a direct significant effect on the dependent variable (employee performance). Furthermore, the mediating variable (communication competence) is significantly influencing the dependent variable (employee performance), which according to Hair et al. (2006) and Baron and Kenny (1986) have met the criteria for mediating influence in partial mediation. Therefore, alternative hypotheses are supported and it can be concluded that communication competence partially mediates the influence of emotional intelligence on employee performance. Thus, the sixth hypothesis is statistically proven. 
Testing the mediating effect of communication competence on the influence of emotional intelligence on employee performance can be seen as follows:

Figure 3. Communication Competence mediates in Partial Mediation

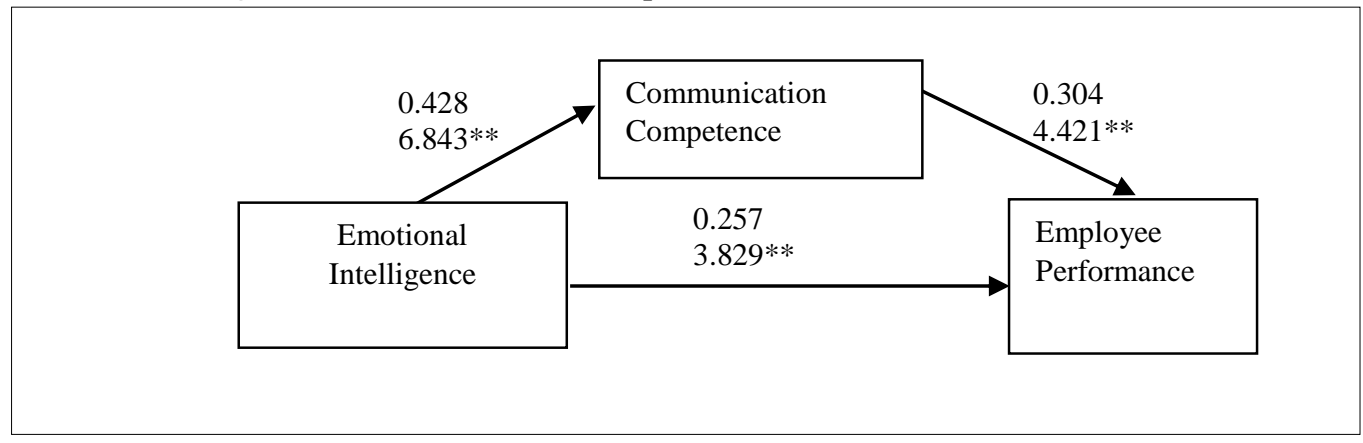

g. Communication Competence mediates the influence of Spiritual Intelligence on Employee Performance

The results of the path test (path analysis) showed that the independent variable (spiritual intelligence) has a direct significant effect on the mediating variable (communication competence) and then a direct and significant effect on the dependent variable (employee performance). Furthermore, the mediating variable (communication competence) significantly influence the dependent variable (employee performance), which according to Hair et al. (2006) and Baron and Kenny (1986) have met the criteria for mediating influence in partial mediation. Therefore, alternative hypotheses are accepted and it can be concluded that employee engagement partially mediates the influence of spiritual intelligence on employee performance. Thus, the seventh hypothesis is statistically proven.

Testing the mediating effect of communication competence on the effect of spiritual intelligence on employee performance can be seen as follows:

Figure 4. Employee Engagement mediates in Partial Mediation

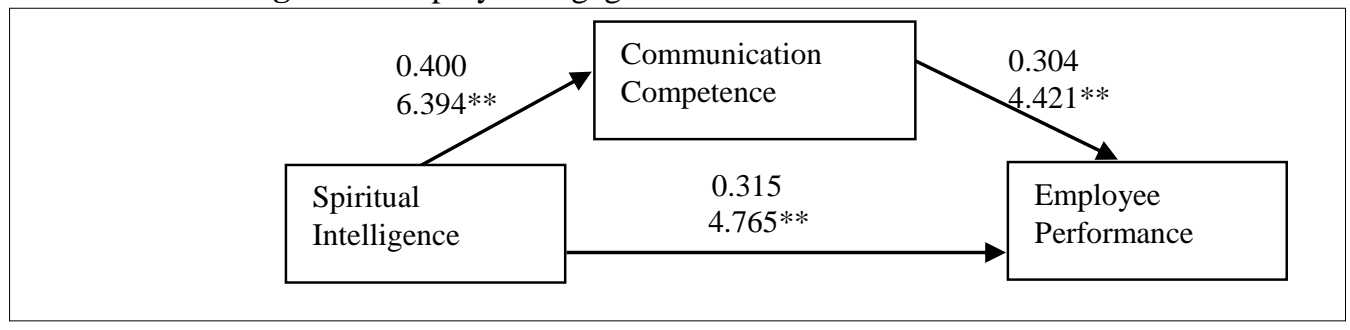

The conclusions of the research hypotheses testing can be viewed in the following table: 
Table 5. Conclusion of Hypotheses

\begin{tabular}{llc}
\hline \hline & Hypotheses & Test Result \\
\hline $\mathrm{H}_{1}:$ & $\begin{array}{l}\text { Emotional intelligence has a positive and significant influence on } \\
\text { communication competence. }\end{array}$ & Accepted \\
$\mathrm{H}_{2}: \begin{array}{l}\text { Spiritual intelligence has a positive and significant influence on communication } \\
\text { competence. }\end{array}$ & Accepted \\
$\mathrm{H}_{3}: \quad \begin{array}{l}\text { Emotional intelligence has a positive and significant influence on employee } \\
\text { performance. }\end{array}$ & Accepted \\
$\mathrm{H}_{4}: \quad \begin{array}{l}\text { Spiritual intelligence has a positive and significant influence on employee } \\
\text { performance. }\end{array}$ & Accepted \\
$\mathrm{H}_{5}: \quad \begin{array}{l}\text { Communication competence has a positive and significant influence on } \\
\text { employee performance. }\end{array}$ & Accepted \\
$\mathrm{H}_{6}: \quad \begin{array}{l}\text { Communication competence mediates the influence of emotional intelligence } \\
\text { on employee performance. }\end{array}$ & Accepted \\
$\mathrm{H}_{7}: \quad \begin{array}{l}\text { Communication competence mediates the influence of spiritual intelligence on } \\
\text { employee performance. }\end{array}$ & Accepted \\
\hline \hline
\end{tabular}

Based on the path analysis results, the size of the direct effects, indirect effects, and total effects between the exogenous and endogenous variables can be found. The test results of the direct effects, indirect effects, and total effects of the path analysis model can be seen in Table 6 .

Table 6: Standardized Direct, Indirect, and Total Effects

\begin{tabular}{ccccc}
\hline $\begin{array}{c}\text { Independent } \\
\text { Variable }\end{array}$ & $\begin{array}{c}\text { Dependent } \\
\text { Variable }\end{array}$ & Direct Effects & $\begin{array}{c}\text { Indirect } \\
\text { Effects }\end{array}$ & $\begin{array}{c}\text { Total } \\
\text { Effects }\end{array}$ \\
\hline $\begin{array}{c}\text { Emotional } \\
\text { Intelligence }\end{array}$ & Communication & 0.428 & - & 0.428 \\
Spiritual Intelligence & Competence & 0.400 & - & 0.400 \\
Emotional & Employee & 0.257 & 0.130 & 0.387 \\
$\begin{array}{c}\text { Intelligence } \\
\text { Spiritual Intelligence }\end{array}$ & Performance & 0.315 & 0.122 & 0.437 \\
Communication & & & - & 0.304 \\
Competence & & & & \\
\hline \hline
\end{tabular}

Based on the research results above, it indicates that emotional intelligence and spiritual intelligence are important elements that directly and indirectly influence employee performance. It is also found that spiritual intelligence is a variable that has the strongest influence on employee performance.

Finding appropriate individuals in an organization is not an easy task. This is because the people needed in an organization is not limited to those with high education or high talent, but there are psychological factors which influence an individual's ability within an organization, such as the ability to manage oneself, the capability to take initiatives, optimism, and the ability to manage one's emotions and think calmly without becoming emotional, which are often referred to as emotional intelligence (Fitriastuti, 2013). Besides that, another form of intelligence, which is spiritual intelligence, can integrate the two other abilities (IQ and EQ), so that it facilitates an individual to think creatively, have future insight, and motivate the individual to work more effectively (Trihandini, 2005). 
These research results support the findings of Trihandini (2005), who reveals that emotional intelligence has a positive and significant influence on employee performance at Hotel Horison Semarang. This finding is also supported by a study from Fitriastuti (2013), who demonstrates that emotional intelligence has a positive and significant influence on the employees of Industrial and Commerce Office in East Kutai Regency. A study by Eman (2014) on supervisors of PT Dock and Shipping Surabaya also concludes that emotional intelligence has a positive and significant influence on the supervisor's performance. Meanwhile, research carried out by Rapareni (2013) supports the hypothesis that emotional intelligence has a positive and significant influence on employee performance of RRI. This research is also backed up by a study conducted by Rahmasari (2012), who finds that emotional intelligence has a positive and significant influence on employee performance.

Support for the concept that spiritual intelligence has a positive and significant influence on employee performance is established by Trihandini (2005) and Rahmasari (2012). Several studies also demonstrate that spiritual intelligence plays a significant role in shaping human behavior and attitudes, such as procrastination behavior and pro-social behavior, as summarized in research carried out by Liling et al. (2013) and Sabiq and Djalali (2012).

These research findings also reveal that emotional intelligence and spiritual intelligence have a positive and significant influence on communication competence. Meanwhile, communication competence has a positive and significant influence on employee performance. The research results also support the findings of Rapareni (2013), who concludes that communication competence has a positive and significant influence on employee performance at RRI. This demonstrates that communication is a significant aspect of work life. Good communication can improve mutual understanding, cooperation, and job satisfaction. Conversely, poor communication has a broader effect on the organization's life, such as conflicts between employees. Individuals who work together in an organization are a group of human resources with an assortment of traits and characteristics so that open communication should be well developed. Employees who have good communication competence will be able to carry out their assigned tasks so that they will have better work performance (Rapareni, 2013).

Communication competence was proven to partially mediates the influence of emotional intelligence on employee performance. This is proven from the result of mediation test in which emotional intelligence has a direct and significant effect on communication competence, and then a direct and significant effect on employee performance. This implies that emotional intelligence can improve employee performance directly and indirectly with the support of high communication competence.

Likewise, communication competence partially mediates the influence of spiritual intelligence on employee performance. This is demonstrated from the mediation test results in which spiritual intelligence has a direct significant effect on communication competence, and then a direct significant effect on employee performance. This shows that spiritual intelligence can influence employee performance directly and it is mediated by communication competence. 


\section{CONCLUSION}

Based on the research hypotheses testing, the following conclusions can be drawn: (1) emotional intelligence has a positive and significant influence on communication competence; (2) spiritual intelligence has a positive and significant influence on communication competence; (3) emotional intelligence has a positive and significant influence on employee performance; (4) spiritual intelligence has a positive and significant influence on employee performance; (5) communication competence has a positive and significant influence on employee performance; (6) communication competence partially mediated the influence of emotional intelligence on employee performance; and (7) communication competence partially mediated the influence of spiritual intelligence on employee performance.

The Islamic Microfinance in Indonesia has great opportunity to be developed. However, certain factors have been slowing down its development. As productivity is one of the factors that determine a success of an institution, Islamic Microfinance Institutions should improve its employees' emotional intelligence and spiritual intelligence to shape and construct good communication competence, so that in turn, it will lead to a productive employee. To the extent of researcher knowledge, there have been limited numbers of researches on the relationship among the variables in this study, especially in the context of microfinance institution in Indonesia. Future research can try to apply the model developed in this study on other financial institutions, both those with sharia basis and conventional basis.

\section{REFERENCES}

Amram, J. Y. (2009). The contribution of emotional and spiritual intelligences to effective business leadership (Unpublished doctoral dissertation). Institute of Transpersonal Psychology Palo Alto, California.

Baron, R. M. \& Kenny, A. D. (1986). The moderator-mediator variable distinction in social psychologicsl research: Conceptual, strategic and statistical considerations. Journal of Personality and Social Psychology, 51(6), 1173-1182.

Castro, P. N. De. (2013). Outcomes of communication competence: A study on a Portuguese restaurant chain. (Unpublished Master's Thesis). Nova School of Business and Economics, Portugal.

Dulewicz, V., \& Higgs, M. (2000). Emotional intelligence: A review and evaluation study. Journal of Managerial Psychology, 15(4), 341-372.

Eman, M. R. A. (2014). Pengaruh kecerdasan emosional terhadap kinerja supervisor dengan efektivitas komunikasi sebagai variabel mediasi. Jurnal Ilmu Manajemen, 2(4), 16661678 .

Emmons, R. (1999). The Psychology of Ultimate Concerns: Motivation and Spirituality in Personality. New York: Guilford.

Fianto, B. A., \& Gan, C. (2017). Chapter 7: Islamic Microfinance in Indonesia. Mircofinance in Asia, 2017, 227-270. https://doi.org/10.1142/97898131479590007

Fitriastuti, T. (2013). Pengaruh kecerdasan emosional, komitmen organisasional dan organizational citizenship behavior terhadap kinerja karyawan. Jurnal Dinamika Manajemen, 4(2), 103-114. 
Goleman, D. (1995). Emotional Intelligence: Why It Can Matter More Than IQ. New York: Bantam.

Hair, J. F., Black, W. C., Babin, B. J., Anderson, R. E., \& Tatham, R. L. (2006). Multivariate Data Analysis (6 $6^{\text {th }}$ ed.). New Jersey: Prentice Hall.

Hein, S. (2007). The Innate Potential Model of Emotional Intelligence. Retrieved January $24^{\text {th }}$, 2019, from https://eqi.org/eidefs.htm

John, D. C. (2011). Emotional intelligence and its role in collaboration. In Proceedings of American Society of Business and Behavioral Sciences $18^{\text {th }}$ Annual Conference (pp. 435445). Nevada: Las Vegas.

Labbaf, H., Ansari, M. E., Masoudi, M. (2011). The impact of the emotional intelligence on dimensions of learning organization: the case of Isfahan University. Interdisciplinary Journal of Contemporary Research in Business, 3(5), 536-545.

Liling, E. R., Nurcahyo, F. A., \& Tanojo, K. L. (2013). Hubungan antara kecerdasan spiritual dengan prokrastinasi pada mahasiswa tingkat akhir. Humanitas, X(2), 59-72.

Novianty, L. (2015). Pengaruh kompetensi komunikasi karyawan terhadap kinerja karyawan di Divisi Pengembangan Dana dan Jasa PT Bank Central Asia, Tbk (Undergraduate thesis, Universitas Mercu Buana). https://repository.mercubuana.ac.id/8770/2/Cover.pdf

Otoritas Jasa Keuangan. (2020). Informasi Umum Lembaga Keuangan Mikro. Retrieved on May $8^{\text {th }}, \quad 2020$, from https://www.ojk.go.id/id/kanal/iknb/Pages/Lembaga-KeuanganMicro.aspx

Payne, H. J. (2005). Reconceptualizing social skills in organizations: Exploring the relationship between communication competence, job performance and supervisory roles. Journal of Leadership \& Organizational Studies Winter, 11(2), 63-77.

Rahmasari, L. (2012). Pengaruh kecerdasan intelektual, kecerdasan emosi dan kecerdasan spiritual terhadap kinerja karyawan. Majalah Ilmiah Informatika, 3(1), 1-20.

Rapareni, Y. (2013). Analisis pengaruh kompetensi komunikasi, kecerdasan emosional dan budaya organisasi terhadap kinerja karyawan radio Republik Indonesia Palembang. Jurnal Ekonomi dan Informasi Akuntansi (JENIUS), 3(1), 35-59.

Sabiq, Z., \& Djalali, M. A. (2012). Kecerdasan emosi, kecerdasan spiritual dan perilaku prososial santri pondok pesantren Nasyrul Ulum Pamekasan. Persona, Jurnal Psikologi Indonesia, 1(2), 53-65.

Salovey, P., \& Mayer, J. (1990). Emotional intelligence. Imagination, Cognition \& Personality, 9(3), 185-211.

Seibel, H. D. \& Dwi Agung, W. (2006). Islamic Microfinance in Indonesia (Working Paper No. 2006-2). University of Cologne, Development Research Center. https://doi.org/10.1355/sj23-1d

Sina, P. G., \& Noya, A. (2012). Pengaruh kecerdasan spiritual terhadap pengelolaan keuangan pribadi. Jurnal Manajemen, 11(2), 171-188.

Taurisa, C. M., \& Ratnawati, I. (2012). Analisis pengaruh budaya organisasi dan kepuasan kerja terhadap komitmen organisasional dalam meningkatkan kinerja karyawan (Studi pada PT. Sido Muncul Kaligawe Semarang). Jurnal Bisnis dan Ekonomi (JBE), 19(1), 170-187.

Trihandini, R. A. F. M. (2005). Analisis pengaruh kecerdasan intelektual, kecerdasan emosi dan kecerdasan spiritual terhadap kinerja karyawan (Studi kasus di Hotel Horison Semarang) (Master's thesis, Universitas Diponegoro Semarang). http://eprints.undip.ac.id/10280/

Tsui, A. S., Pearce, J. L., Porter, L. W., \& Tripoli, A. M. (1997). Alternative to the employeeorganization relationship: Does investment in employees pay off?. The Academy of Management Journal, 40(5), 1089-1121. 
Wolman, R. (2001). Thinking with Your Soul: Spiritual Intelligence and Why It Matters. New York: Harmony.

Yadav, N. (2011). Emotional intelligence and its effects on job performance: A Comparative study on life insurance sales professionals. International Journal of Multidisciplinary Research, 1(8), 248-260.

Zeffane, R., Tipu, S. A., \& Ryan, J. C. (2011). Communication, commitment and trust: Exploring the triad. International Journal of Business and Management, 6(6), 77-87.

Zohar, D., \& Marshall, I. (2000). SQ: Connecting with Our Spiritual Intelligence. New York: Bloomsbury. 